\title{
O JUSNATURALISMO CLÁSSICO
}

Giovanne Henrique Bressan Schiavon

SUMÁRIO: 1.Introdução. 2.O Jusnatutalismo. 3.O Estado eo Direito na Antiguidade 3.1.Os Gregos. 3.1.1.A sofística. 3.1.2.Sócrates, Platão e Aristóteles. 3.1.3.O pensamento pósaristotélico. 3.2.Os Romanos. 4. Conclusão. 5. Bibliografia.

SUMMARY: 1.Introduction. 2. Jusnaturalism. 3. State and Law in Antiquity. 3.1. The Greeks. 3.1.1. The Sophistic. 3.1.2. Socrates, Plato and Aristotle. 3.1.3. Post-aristotelian thought. 3.2. The Romans. 4.Conclusions. 5. Bibliography.

SUMARIO: 1. Introducción. 2. Jusnaturalismo. 3. Estado y ley en Antigüedad. 3.1. Los Griegos. 3.1.1. La Sofistica. 3.1.2. Sócrates, Platón y Aristóteles. 2.1.3. Pensamientos Poste-aristotélicos. 3.2. Los Romanos. 4.Conclusiones. 5. Bibliografia.

RESUMO: Apresenta-se o modelo de racionalidade da Antigüidade, especificamente o pensamento grego e romano, como estrutura ética jurídica material influenciada pela filosofia.

ABSTRACT: The model of rationality by antiquity, especially the Greek's and Roman's thought is analyzed like ethical-material-juridical structure represented by philosophy.

RESUMEN: El modelo de la racionalidad por antigüedad, especialmente los pensamientos griego y romano es analizado como la estructura ético-material-juridica representada por la filosofia.

PALAVRAS-CHAVE: Filosofia do direito. Jusnaturalismo. História do direito.

Mestrando en Direto Negocial da Universidade Estadual de Londrina. Professor do Outso de Direito da Faculdade Daranaense (FACCAR). 
KEY-WORDS: Jurisprudence. Philosophy. Jusnaturalism. Law's history.

PALABRAS LLAVES: Jurisprudencia. Filosofia. Jusnaturalismo. Historia de lo derecho.

\section{Introdução}

O presente artigo traz alguns aspectos da história do pensamento humano contrapostos à doutrina do direito, com o objetivo de caracterizar a teoria do direito natural - em sua proposta original - o "jusnaturalismo clássico". A exposição é informal, não se preocupa fornecer datas e visa aclarar conceitos para exposições mais detalhadas que virão a seguir ${ }^{1}$.

É certo que, cada época possui uma explicação própria do seu modo de viver. Ainda que em tais épocas não se tivesse a percepção sobre seu próprio viver, esse modelo de racionalidade, criado inconscientemente, guia os indivíduos, ou seja, o grupo se orienta a partir dessa autocompreensão dos fenômenos cotidianos ${ }^{2}$.

Assim, busca-se identificar a racionalidade debatida pelos pensadores da antigüidade. Vale destacar que, se, de um lado, o direito, ao selecionar as condutas desejáveis, estabiliza a sociedade e por isso é adaptado, conforme a estrutura social evolui ou regride. Por outro lado, a filosofia tem-se esforçado, desde as suas origens, para explicar o mundo em sua totalidade, refletindo a racionalidade de cada época. Justifica-se, então, utilizar-se dos problemas versados por teorias filosóficas para apresentar um dado sistema jurídico ${ }^{3}$.

Assim, inicia-se pela conceituação do jusnaturalismo (1), para depois discutir a compreensão do direito e do Estado pelos antigos (2) especificamente dentre os gregos (2.1) - aqui destacados a sofistica (2.1.1), Socrátes, Platão e Aristóteles (2.1.2) e o pensamento pós-aristotélico (2.1.3) - e os romanos (2.2). Para em conclusão, tecer consideraçôes sobre as características do pensamento antigo.

\footnotetext{
cf. FUSTEL DE COULANGES, Numa Denis. A cidade antiga. Trad. Fernando de Agutar, 4 ed, Säo Paulo: Martins Fontes, 1998, p. 123: "(...) no estudo de sociedades antigas as épocas indican-se mais facilmente pela sucessão das idéas e das instituições que pela secuuència dos anos (..."

"sobre essa explicação de modelo de racionalidade cf. HANSEN, Gilvan Luiz. Modemidade, mopia e taballho. Prefácio de Leonardo Prota. Londrina: CEFI 1999.

"HABERMAS, Jürgen. Teoria da acción comunicativa Trad. Manuel Jiménez Redondo. Madrid: Tautus, 1988. p. 15. Tomo It racionalidad de la accion y racionalización social.
} 


\section{O Jusnaturalismo}

A escola do direito natural, ou a teoria do jusnaturalismo, é uma corrente jusfilosófica que sustenta a existência de leis objetivas que espelham uma ordem preestabelecida e na possibilidade de seu descobrimento por meio da razão. Assim, a validade do ordenamento jurídico (ou o seu reconhecimento como um poder, pelos membros da comunidade) é obtida por meio de sua identificação com essa ordem superior objetiva ${ }^{4}$.

Conforme o sistema de idéias adotadas, divide-se os períodos do direito natural em três: clássico, teológico e racionalista (ou moderno). No jusnaturalismo clássico, no mundo antigo, com sua interpretação mítica da realidade, a razão aparece como meio de explicar o mundo em seu conjunto, a unidade na diversidade dos fenômenos. Esse pensamento oriental, ao final, é absorvido pelos romanos. Já no jusnaturalismo teológico - da Idade Média - a razão constitui-se no melhor caminho para se aceder à revelação divina. Gradualmente, as idéias cristãs incorporam influências germânicas, romanas e da filosofia oriental. Por fim, no jusnaturalismo moderno (ou racionalista) - resultado das idéias do renascimento e da ilustração - as teorias do contratualismo são resgatadas para fundamentar racionalmente o Estado.

Pode-se, então, indicar como característica comum às propostas do direito natural, referirem-se ao conjunto do mundo, da natureza, da história e da sociedade, no sentido de um saber totalizante. Acarretando no, que se acostumou denominar como, dualismo jurídico. Uma hierarquia de leis, segundo a qual o direito positivo permanece subordinado a moral, ou a um direito natural, recebendo dela sua orientação. Assim, na teoria do direito natural, idéias clássicas, a moral teológica e a moral racional se revezam como padrão para o discurso constituinte do direito. Na qual, a autonomia dos cidadãos coincide com a vontade livre de pessoas morais e o direito natural forma o núcleo do direito positivo.

\footnotetext{
cf. BOBBIO, Norberto. Locke co direito natural. Trad. Sérgio Bath. Brasilia: UnB, 1997 p. 60; OST, François. "Prólogo" apud FALCON Y TELLA, Maria Jose. Concepto y fundamento de la walidez del dercho. Madrid: Civitas, 1994. p. 16; e, FARINAS DULCE, Maria Joséc El problema de la validez juirdica. Prol. Gregorio Peces-Barba, Madrid: Givitas, 1991. p. 39.

${ }_{5}^{5}$ Importante esclarecer que, conforme a tradição kantiana a moral é constituida por normas universais que indicam o certo e o errado e que continuam valendo mesmo que ninguém do grupo as sigam Cf. PALOMBELLA, Gianluigi. Filosofa del derecho: moderna y contemporinea. Trad. José Calvo Conzález. Madrid: Tecnos, 1999 p. 15-6: "No plano flosófico e no epistemológico, os postulados téricos característicos do jusnaturalismo, enquanto doutrina do direito natural, conduzem a prestimir a existência de um direito ulterior e distinto do direto postivo e vigente, e em tudo diferente a este ultimo; em geral, se trata de um direito concebido com o proposito de constituir o fundamento éticonatural sobre o qual se apóia ou deveria apoiar o direito positivo... Devido a esta b́tica cognitivista e objetivista, o jusnaturalismo é também prevalentemente um "derivacionista": de fato, não só considera possivel conhecer universalmente verdades objetivas (como pertencentes à realidade da natureza, do ser, dos fatos), mas que delas deriva proposiçoes normativas, precetos: cai assim naquela falácia naturalista, que constitui um indevido salto lógico do ser ao dever ser". (traduçäo livre); vd. também, HABERMAS, Jürgen. Direito e denocracia: entre fachicdade : valtade Trad. Flávio Beno Siebeneichler. Rio de Janeiro: Tempo Brasileiro, 1997. vol. II, p. 309.
} 


\section{O Estado e o Direito na Antigüidade}

Com apoio no conhecimento antropológico, é possível afirmar que o direito, enquanto instrumento que possibilita a vida em sociedade, precede o surgimento do poder político, organizado no Estado. As leis (o direito institucionalizado pelo Estado) e a administração (o poder do Estado organizado juridicamente) surgem simultaneamente, na forma de poder político. Diz-se então que, o desenvolvimento do direito resultou no poder político soberano, "no qual o poder do Estado e do direito do Estado se constituem reciprocamente".

Em sociedades tribais, não há procedimentos judiciais, os conflitos internos se sujeitam à vingança privada (desafio), ao misticismo, com a invocação ritual de forças mágicas (oráculo) e a mediação de um árbitro (a qual se apresenta como equivalente pacífico para a violência e a feitiçaria). $O$ árbitro não tem jurisdição, nem pode conferir executoriedade para suas decisões, sua atuação é condicionada pela vontade das partes?.

Por isso, deve-se atentar à dificuldade existente para as populações primitivas fundamentarem sociedades regulares. Neste sentido Fustel de Coulanges sustenta que para o surgimento do vínculo social, ou seja, para a instituição de um comando que se fizesse acatar pela obediência, foi necessário algo mais forte do que a força material, a "crença":

"(...) Nada de mais poderoso existe sobre a alma. A crença é obra do nosso espírito, mas não encontramos neste liberdade para modificá-la a seu gosto. (...) O homem pode dominar a natureza, mas está sempre sujeito ao seu próprio pensamento." ${ }^{\text {. }}$

\subsection{Os Gregos}

Antes de apresentar os sofistas, são necessárias algumas observações, o pensamento grego não começa com a sofística e nada do que os sofistas escreveram sobreviveu até o presente, as análises têm sido feitas a partir de seus comentadores ou opositores, especialmente pelos diálogos platônicos. Justifica-se a eleição da sofística, como ponto de partida, face ao momento histórico, de seu apogeu, marcar a entrada da Grécia em seu período de ilustração. No qual, a cultura grega se emancipa da religião e simultaneamente o poder político se democratiza.

\footnotetext{
${ }^{\circ}$ HABERMAS, Jürgen. op. cit., p. 233-4.

"HABERMAS, Jürgen op. cit., p. 2345.

"FUSTEL DE COULANGES. op. cit.s p. 139-40.
} 
Até então, os mitos sobre os deuses, desempenhavam o papel de narrativa sobre a origem de algo (dos astros, da Terra, dos homens, das plantas, etc.). Esse discurso era proferido para ouvintes que o recebia como verdadeiro, porque confiavam naquele que narra. Baseava-se, portanto, na autoridade e confiabilidade da pessoa do narrador. Nesse contexto, os deuses gregos personificam as qualidades e os defeitos morais do homem, culminando por se constituir em idéias e forças que existem e obram entre os homens e para os homens?.

Assim, os sofistas, percebendo as contradições e limitações dos mitos, foram racionalizando essas narrativas, transformando-as numa outra coisa, numa explicação inteiramente nova e diferente. A direção do poder político, era obtida pela retórica - transmitida de pai para filho como técnica política - o que se refletiu na transformação dos interesses filosóficos ${ }^{10}$.

Observe-se que, se antes os mitos desempenhavam função de coesão político-jurídica, agora a sofística reformula os mitos, partindo da natureza empírica do homem e converte-a como fundamento dos mitos e consequentemente de determinadas exigências jurídicas ${ }^{11}$.

Há que se destacar, contudo, que o pensamento grego não constitui um todo unitário, pelo contrário, a necessidade de se determinar o ser do homem, fez surgir duas formas contraditórias de direito natural. Uma delas o direito natural idealista (ou intelectualista), acreditava poder determinar o ser do homem pelos caracteres comuns a todos, e o direito natural empirista, o qual define o ser do homem partindo dos caracteres de cada indivíduo concreto. Assim, no direito natural clássico, os pensadores vislumbram o indivíduo inserto numa realidade objetiva. Assim, ou a vontade é explicada como mero cumprimento possibilidades ideais predeterminadas, ou cede lugar ao instinto natural ${ }^{12}$.

\footnotetext{
"CHAUI, Marilena. Convite â filosofia. 12a. ed, São Paulo: Atica, 1999. p. 28 e 31; COSTA, op. cit., p. 8; WELZEL, Hans. Introducion a ha hlosofiat del derecho: Derecho natural y justicia material. Trad. Felpe Gonzatez Vicen, 2 ed. Madrid: Aguilar, 1974. p. 6.

"WELZEL, op. cit., p. 12.

"Wbid, p. 10.

12 COSTA, Fausto (El delito y la penat en la historia de la fllosofia. Trad. Mariano Ruiz-Funes. Cidade do Mexico: Uteha, 1953) esclarece às p. 281 que, somente a civilização mediterrẩnea começou a pensar a desvinculaçăo da objetividade material. Se a alma é considerada como contribuiçăo da religião persa, foi a vontade abbitráia do Deus hebreu que colocou "entre o espirito e o genero humano o abismo do cé". Nesse sentido, WELZEL, op. cit. p. 46: Em ambas as concepços, se ignora a pecularidade especilica do ato volitivo [no intelectualismo] não ha lugar nem para a impenetrabitidade racional da decisto na situaçáo concreta, nem para a live criagăo de novas possibilidades de decisão volitiva.
} 


\subsubsection{A sofistica}

Destaca-se, na sofística, três autores Protágoras de Abdera, Cálicles e Trasímaco, cada qual esposando uma particular concepção do direito.

PROTÁGORAS DE ABDERA explicava a cidadania na condição moral do indivíduo. $O$ indivíduo não tem seu direito à participação condicionado por seu conhecimento, ou sabedoria, mas, na capacidade de reconhecer o bem e/ou mal. O individuo é a medida de todas as coisas. Essa medida, na prática implicava em que a determinação do justo e do injusto vincula-se à opinião geral e pública. Se o que era verdade para um, não obrigatoriamente seria verdade para outro, o julgamento moral se transforma em algo coletivo subjetivo, impedindo a existência de uma verdade objetiva no campo éticopolítico, posto que tudo dependeria da opinião da maioria.

Identifica-se aqui, a primeira tentativa de se justificar a democracia por meio do relativismo subjetivo. Uma teoria democrática da sociedade e do Estado, que reconhece, inclusive, uma concepção contratualista da origem da sociedade. Na prática jurídico-penal, a contribuição mais notável de Protágoras é uma preconizada função preventiva da pena, recepcionada por Platão e depois resgatada pelo jurista romano Seneca ${ }^{13}$.

CÁLICLES, por sua vez, formula uma visão particular da origem contratual da sociedade. O contrato teria existido como um acordo dos fracos para controlar os fortes, os quais naturalmente devem governar. $\mathrm{O}$ direito existe, então, na medida da força. Natural, aqui, adquire o sentido de animal, não só porque as analogias traçadas remete a esse raciocínio, mas também porque, para ele, não há nada que distinga os homens dos animais. O homem se vê reduzido a uma coisa, como um computador programável.

TRASÍMACO assemelha-se a Cálicles, ao explicar a justiça como a vantagem do mais forte. Tal para Karl Marx (séc. XIX) o direito seria uma superestrutura ideológica que impóe os valores da classe dominante, qual para Trasímaco o direito é sempre expressão do poder. Ocorre aqui a adoção de determinadas características empírica do homem como fundamento de determinadas exigências jurídicas. Então, por exemplo, se o homem tem a capacidade de pensar em grupo, esse grupo obrigará àquele o indivíduo, e daí por diante, os indivíduos serão dominados pelo grupo ${ }^{14}$.

6 WELZEL, op cit, p. 7-8; e, ZAFFARONI, Eugenio Raul, Manual de derecho penal, Parte general. 6a. ed. Buenos Aires: Ediar, 1991. p. 196.

- WELZEL, op. cit, p. 12; e, ZAFFARONI, op cit., p. 197. 
Em suma, na sofistica já aparece uma profunda problemática do direito natural: a estrutura protéica do individuo toma nas mãos de cada sofista a forma que ele deseja. Tudo o que tem por justo e desejável é introduzido já de antemão, tacitamente, em seu conceito da natureza do homem, antes de extrá-lo, de novo, para justificar sua noção do justo por natureza ${ }^{15}$.

\subsubsection{Sócrates, Platão e Aristóteles.}

SÓCRATES, de sua parte, levou os estudos da sofistica ao seu clímax, terminando por superá-lo. $O$ pensamento socrático também participou da transição do pensamento cosmológico ao pensamento antropológico, o que o levou adotar uma postura crítica frente à ordem tradicional. Todavia, em vez de aceitar o subjetivismo e o relativismo da sofística, ele propôs o auto-conhecimento como forma de acesso à esfera objetiva de uma verdade subtraída de toda dúvida'.

Sócrates, especificamente, tratou de assentar a base para uma nova ordem vinculante. A partir do interior, por um aprofundamento da subjetividade destacada pela sofística, até o exterior, buscando o aceso à esfera objetiva de uma verdade subtraída de toda dúvida. O fundamento de todo comportamento moral é o domínio de si, vale dizer, o domínio da razão sobre as paixões, o qual conduz ao equilíbrio interno, e à harmonia da alma. Só aquele que conseguiu o domínio sobre si, sobre suas paixões, é um homem livre; enquanto que o que não aceita dominarse é um escravo de seus instintos, não um homem livre.

Então, a paixão deve ser dominada pela razão. Essa afirmação vincula o conceito de liberdade à ação moral do homem, que não deve se deixar escravizar por seus instintos. No domínio de si socrático, não se vislumbra autonomia ${ }^{17}$, contudo, o conceito de liberdade se encontra mais aprofundado do que na sofística. Aqui, a liberdade, caracteristica da pessoa moral, decorre do domínio de si. O cidadão, é chamado à livre participação no processo de formação da vontade estatal.

\footnotetext{
15. WELZEL, op, cit., p. 12.

16 Ibid, p. 13.

17 Ibid, p. 13.4. En teoria politica autonomia, tradicionalmente, assume o significado de capacidade da pessoa en eleger suas próprias normas. De acordo com Kant, ação autônona é aquela na qual o sujeito aceita e afirma a ordem objetivamente como própria da obrigação interna, no passo que na ação heterônoma se reduz ao cumprimento cego da obriģą̧ăo ético-material como se tratasse de un imperativo alheio à obrigação.
} 
Sócrates parece ter por idênticas a justiça e a legalidade, aceitando a definição da lei como a determinação escrita do que, por acordo dos cidadãos, deve-se fazer ou omitir. Para ele é do gosto dos deuses que o justo e o divino constituam um todo, assim não distingue a justiça da legalidade, onde ninguém poderia ordenar coisas justas que não se harmonizem com a lei divina. Só dentro dos limites permitidos pela lei pode-se negar obediência aos mandados do poder ${ }^{18}$.

Desta feita, a justiça constitui-se em guia da conduta humana. Solucionado o problema ético-subjetivo do agir, vale dizer, a determinação do que deve guiar a conduta, Sócrates trata do problema ético-objetivo, ou seja, eleição do que é (ou qual é) o conteúdo do conceito de justo. Não por um interesse conceitual e teórico, mas pelo propósito prático de superar o relativismo da sofística por meio da determinação de um conceitos indiscutível, de "idéias" de validade objetiva, que norteariam o agir ético.

Sua maior contribuição, não foi a obtenção desse conteúdo, mas a afirmação de que a conduta deve ser ordenada por um saber de validade geral objetiva. Sobretudo, Sócrates foi o primeiro moralista. Seus ensinamentos constituem uma defesa à obediência das leis. É emblemático que, condenado à morte por um tribunal, ele aceite (mesmo com a possibilidade de fuga) executar a pena ingerindo veneno. Seus comentadores, interpretam que cumpre a sentença na crença de que os juízes terão que render contas pelo injusto da sentença aplicada. Assim sua obediência, não significaria uma confirmação do dever mas uma tentativa de restabelecer a ordem juridica total ${ }^{19}$.

PLATÃO. O pensamento socrático inspirou o platônico, também a ele incomodava o subjetivismo e o relativismo dos sofistas. Sócrates, ao apresentar o indivíduo como um sujeito que através do conhecimento poderia dominar as paixões e se aprimorar, conferiu ao problema éticoobjetivo uma nova solução, ou seja, se a realidade empírica é cambiante e mutável (por ser objeto de opinião insegura e defeituosa) resta encontrar as idéias que não sejam resultado de mera opinião subjetiva, mas um saber seguro dotado de validade geral imune às mudanças ${ }^{20}$.

Platão distingue duas realidades: um mundo visível (sensível) ou mundo dos reflexos e o mundo invisível (inteligível) ou mundo das idéias.

\footnotetext{
\&WELZEL, op ct. p. 145; e, COSTA, op. cit, p. 10.

WELZEL, op ch, p. 16.

23ELZEL, op. ch, p. 167
} 
Com essas idéias, objetivos de um conhecimento de validade geral estrita, eterna e universal, Platão, explica a organização social. Paradigma que permite a construção de um direito natural ideal, desvinculado da religião. Nele, os deuses não são os legisladores do mundo, até mesmo estes vinculam-se àqueles conceitos, verdades racionais de justiça. Os quais assumem a explicação de relação adequada dos estratos entre si, de tal sorte que cada indivíduo realiza o que lhe é próprio. Assim, quando a razão domina, os estratos inferiores guiam-se pelas idéias ${ }^{21}$.

Efetivamente, o idealismo vincula a realidade às formas (ou às idéias) que expressa. Daí dizer que, real não o objeto (a cadeira ou a mesa,...) tocado e sentido, senão a idéia que se tem dele. Enquanto não se tem a idéia do objeto, este não existe, o conhecimento é anterior à captação da realidade. O modelo platônico, além de possibilitar a reduplicação em sistema normativo positivo e ordem normativa ideal, pode servir de base para a formulação teórica de um sistema político autoritário. Pois, ao declarar que os valores independem da análise das condutas como boas ou más, adota-se um objetivismo-valorativo, o qual afasta a possibilidade de revisão de seu conteúdo ${ }^{22}$.

Note-se que, os que detém o conhecimento são chamados a guiar os menos esclarecidos. Ao governo, exercido por sábios, compete ensinar ou, em caso de resistência, eliminar o delinqüente. Realmente, dada a existência de várias culturas humanas: uns sabem outros não, alguns são suscetíveis à educação outros não. Platão propõe para esses que não aceitam correções exteriores o banimento ou a pena de morte. Enquanto, que para aqueles que podem ser educados, prevê o uso de sançôes graduadas, não sobre o elemento objetivo do dano provocado, mas sobre o elemento subjetivo, ou intenção criminal.

A sanção é tida por Platão como um ato de justiça. O trabalho de correção do indivíduo visa lhe salvar a alma, como uma medicina da alma. Tal a economia libera o indivíduo da indigência, qual a medicina sara o corpo, o direito, por meio da pena, faz-lhe conhecer a verdade. Fundamenta filosoficamente, a tese de que a coação para o bem é também boa moralmente e lícita. Uma vez que se crê na posse da verdade absoluta, pode-se desprezar o princípio moral do livre cumprimento do dever e do respeito a liberdade individua ${ }^{23}$.

\footnotetext{
${ }^{21}$ Ibid, p. 18.

2. ZAFFARONI, op cit, p. 199.

2 COSTA, op. cit, p. 14.
} 
Em sua obra da maturidade ("As leis"), após malogradas experiências na política. Conclui que qualquer homem ao desfrutar de poder absoluto sobre outros homens, termina por se corromper. Talvez, por isso, aduz que é a lei que deve governar, não o homem (ou a solidariedade).

ARISTÓTELES. Se Platão parte das idéias como critério que revela a realidade, terminando por separar as idéias dos objetos, Aristóteles, por sua vez, parte da realidade concreta, aqui os objetos são compostos de matéria e forma, um princípio potencial (ou determinável) e um princípio formal (ou determinante). Assim, a forma determina a espécie da coisa e origina a idéia que se faz dela ${ }^{24}$.

Efetivamente, a maior contribuição aristotélica é a fixação do conteúdo da matéria que se conhece por metafisica. $\mathrm{Na}$ filosofia entende-se por metafísica, o conjunto de questões, formuladas por Aristóteles, as quais foram organizadas em um tratado que foi colocado após o tratado da física (daí o nome) e cuja pergunta mais importante - o quê é o ser? constitui o centro da ontologia. A mesma ontologia, é o centro de qualquer metafísica e para alguns a esgota ${ }^{25}$.

Como exemplo, pode-se citar a semente: em ato ela é semente, em potência é árvore. Quando a semente for semeada e nascer a árvore, em ato ela será árvore, em potência é fruto, tábua, lenha ... A forma varia, mas somente em função da potência, uma semente não se transmuda em pássaro ${ }^{26}$.

No livro "Ética à Nicômaco", Aristóteles desenvolve que as ações são os indicadores da potência. Três conceitos se destacam: a virtude entendida como meio-termo; a felicidade como finalidade de vida ética; e, a prudência critério ético fundamental é da ação. A vida humana tem por finalidade a felicidade, o mecanismo para se atingir essa finalidade é a prudência que em última análise seria o equilíbrio.

Confere, desse modo, um particular conceito à natureza. Um conceito finalístico (ou teleológico), no qual o natural é algo predeterminado conforme os pontos de vista axiológicos. Onatural tem que ser encontrado nas coisas em que se encontram em seu estado originário, não naquelas que degeneraram ${ }^{27}$.

Por igual, a organização do Estado, em Aristóteles, é explicada, não do modo contratual, mas na natureza (finalidade) do homem, $\mathrm{O}$ homem é um animal político e por natureza é destinado a formar comunidades

\footnotetext{
27 ZAFEARONI, op cit, p. 199.

ZAAFARONI, op. cit, p. 199-200.

3. MONDOLFO, Rodolfo. O pensanento antigo. Trad. Lycurgo Gomes da Motta, rev. Vicente Felix de Queiroz, Vol. I, Săo Paulo, Mestre Jou, 1973.

2 ARISTOTELES apud WELZEL, op. cit, p. $25-6$.
} 
estatais, é uma necessidade a qual interfere na sua condição de sobrevivência. Esse mesmo fundamento será resgatado no séc. XVIII por Montesquieu ${ }^{28}$.

Quanto ao conceito de justiça e lei, inicialmente, adota o conceito tradicional que identificava justiça com o agir de acordo com a lei. Mas depois, formula uma distinção entre o justo por lei (particular) e o justo por natureza (geral). O primeira é estabelecido pelos homens, bem seja a lei escrita ou não escrita, enquanto que o geral é o Direito natural, tem a mesma força por toda a parte, e não depende das opiniôes e dos decretos dos homens ${ }^{29}$.

Aristóteles, no que se refere ao estudo da imputação e da responsabilidade, adota o princípio do "domínio do fato". Para ele, uma ação só é imputável se se encontra em poder do agente, ou se ele é seu dono, de tal maneira que também poderia agir de outro modo. Só a ação imputável é suscetivel de valoração e de censura. Desenvolveu, assim, princípios que se transformaram em idéias permanentes às estruturas materiais do delito, aprimoradas após, por Tomás de Aquino e Puffendorf ${ }^{30}$.

Sobre a pena, embora a doutrina aristotélica tenha por constante realizar aquela felicidade consistente na atividade virtuosa - o real fim da república - ela compartilha da tese de que as pessoas não se submetem a uma ordem por pudor, mas por medo. As leis são necessárias, porque as pessoas não seguem a palavra, somente a força. A lei, além de oferecer bons preceitos para a virtude, contempla a aplicação de sanção para seus transgressores. Apresenta como um meio necessário para conseguir o fim moral a que se propõe a união civil. É essencialmente dor, porque quem provoca dor com dor deve ser castigado ${ }^{31}$.

Por fim, com Aristóteles se esclarece que, devolver o mal por mal poderá ser um critério adequado para a justiça comutativa, mas não para o penal. Por exemplo, imagine uma situação na qual um juiz golpeia um cidadão qualquer: em tal caso será excessivo castigar ao autor das lesões com outras lesões. Pelo contrário, se um cidadão golpeia um juiz, os golpes de igualdade não serão suficientes para integrar a medida da pena. É necessário um critério mais completo e que se adapte a situação concreta dos $\operatorname{casos}^{32}$.

\footnotetext{
ZAFFARONI, op cit, p, 199.

WELZEL, op Ci, p. 27-8.

"COSTA, op cit, p. 16\%; e, WELZEL, op. cit, p. 301.

aOSIA, op. cit, p. 17

Ibid.
} 


\subsubsection{O pensamento pós-aristotélico.}

Como reflexo às idéias platônicas e à metafísica aristotélica apresentase Epicuro, quem ao buscar o ideal do homem prudente e ao conviver com a decadência política da Grécia, propôs uma doutrina ética individualista. $\mathrm{Na}$ qual o indivíduo, independente do Estado, deve solucionar por si seus problemas, buscando a sua satisfação individual ${ }^{33}$.

Importante considerar que, o epicurismo resgatou o conceito e fundamento das leis, dos sofistas. Assim, não haveria na sociedade nada natural, tão só convençôes precárias, contratadas pelos homens à luz de determinadas vantagens. Identifica-se aqui, a primeira formulação da teoria que identifica o justo com o útil. Surgem vinculados o princípio utilitário e o contratual, a partir de então, um sempre invocará o outro na história da filosofia.

Para os epicuristas: " (...) a justiça não é uma coisa que possua vida por si mesma existente e imutável, mas unicamente um reflexo do comércio reciproco dos homens, que varia de lugar a lugar e de um a outro tempo" ${ }^{34}$.

O estoicismo, por sua vez, soluciona o problema ético-objetivo apelando para um fundamento distinto da satisfação individual. Consequentemente o indivíduo deve observar sua natureza e a lei, ou seja, a força criadora universal e a razão. "A vida racional e natural é um. dever que se vem cumprindo mediante a subordinação à lei"3.

Se de um lado, os epicuristas eram individualistas e acreditavam na liberdade individual, de outro os estóicos apresentavam princípios metafisicos que prodamam a necessidade universal das coisas. Assim, a realidade estania predeterminada, cabendo ao individuo seguir ou resistir ao seu destino. Todavia, a resistência era ineficaz pois não há como escapar do seu lugar no grande ciclo. A liberdade então não seria uma característica natural, mas resultado do progresso moral ${ }^{36}$.

Com esse substrato teórico, os estóicos enfrentaram o problema da responsabilidade, partindo da premissa de que o sentido do ciclo pode ser compreendido por qualquer homem que se dedique a isso, o pecado é a ação contrária ao dever, é indiferente qual pecado foi praticado (todos eram iguais). Contrariamente os epicuristas diferenciava os pecados conforme sua gravidade ${ }^{37}$.

\footnotetext{
COSTA, op. ct, p. 19-23; e, WELZEL, op. cit, p. 3344

AOSTA, op cit, p. 1920 .

Ibid, $\mathrm{F}, 2 \mathrm{~L}$.

${ }^{36}$ COSTA, op. cit, p. 21-2; c, ZAFFARONL, op cit, p. 200.

${ }^{37}$ COSTA, op cit, p. 22; e, ZAFFARONI, op. cit, p. 200.
} 
Há que se reconhecer a contribuição dos estóicos às primeiras valorações casuísticas das ações humanas. Diferem a ação simplesmente conveniente (correspondendo a uma exigência externa da ação) e a ação boa em si mesma (realizada com a intenção de fazer o bem). Distinção que fundamentará a diferenciação entre "rectum", "honestum" e moralidade do jurista romano Marco Túlio Cícero, pelo que se diz que o estoicismo contém o gérmen de uma das mais importantes doutrinas sobre os caracteres diferencias entre moral, ética e direito ${ }^{38}$.

\subsection{Os Romanos.}

O império romano em seus mil e trezentos anos de história elaborou o mais refinado sistema jurídico da antigüidade. Mais políticos e juristas do que filósofos, os romanos captaram a essência das doutrinas de caráter prático gregas. Ressalte-se que, os pensadores romanos iniciam o esforço da diferenciação da moral e o direito. Talvez porque, os conceitos jurídicos, foram sendo burilados, no exame das questões concretas, e as instituições jurídicas modelaram-se através da contribuição dos administradores, dos doutrinadores e dos juizes, sem que, entretanto, houvesse a preocupação de delimitar teoricamente os campos da atividade humana ${ }^{39}$.

MARCO TÚLIO CÍCERO. Na fase republicana, o pensamento romano, tem por porta-voz Cícero, o qual normalmente é explicado em conexão com as idéias gregas. Entretanto, seu conceito de cidadania, ou seja, a subordinação do cidadão à lei, mesmo quando exista disparidade entre os valores individuais e os coletivos, não é explicada com o auxílio dos textos gregos. A cidadania romana tem sua origem associada ao espírito do povo romano, mais pragmático do que os gregos ${ }^{40}$.

Essa inovação, na qual o indivíduo se desintegra ante o coletivo, apesar de notável, não rompe completamente o modelo oriental. Ou seja, se por um lado, no espírito romano predomina a vontade, a consciência imediata, o consenso comum, no lugar do intelectualismo universalista oriental, por outro, essa adesão do cidadão à lei continua sendo obtida por veneração, por temor e por interesse.

A obra, "De legibus", livro primeiro, expõe a concepção de uma lei natural e divina, ditada pela razão reta, escrita e não escrita, com a qual

\footnotetext{
COSTA, op. cit, p. 22-3.

"CF. REALE, Miguel. Filosotia do direito. 19" ed. Säo Paulo: Saraiva, 2000. p. 626-32.

* DILTHEY apud CORTS GRAU, Jose. Historia de fa flosofia del derecho. 2a ed., Tomo I, Madrid, Nacional, 1968, p. 17\%; c, COSTA, op. cit, p. 25-6.
} 
deve conformar-se todo o direito positivo. Esta lei representa o bem supremo e o dever absoluto. $O$ direito não deve ser buscado no edito do pretor, nem nas doze tábuas, mas por via filosófica na natureza do homem. A lei injusta não converte-se em justa, porque os governantes possam impô-la, nem sequer quando os súditos a cumprem ${ }^{41}$.

O direito de castigar, então, é explicado por força da justiça natural e divina. Castiga-se para fazer justiça. Por outro lado, o injusto, também, não dependerá de valoração, existirá por si, sem necessidade de referência ao outro. Ora, se o injusto é a violação da lei natural e divina, e essa é eterna e imutável, o que é injusto hoje será injusto sempre, independente da consideração humana.

Assim, pode-se sustentar que, no mundo romano surge a figura do direito natural identificada com a própria moral, servindo de pressuposto ao direito positivo, expressando certos princípios gerais de conduta, como exigências imediatas e necessárias da racionalidade humana ${ }^{42}$.

Como acreditar que o homem conhecendo o bem, opte pelo mal, afastando-se da lei natural? Qual o fundamento da culpa? Cícero enfrenta essas indagações, reconhecendo que o homem nasceu para obrar com justiça, mas se não o faz, é porque, como ensinavam os estóicos, a virtude não se improvisa, é uma conquista do homem. Assim, aquele que faz o esforço necessário para se aperfeiçoar, cuidando do espírito e do corpo, é o homem de bem, aquele que toma em consideração o útil distinguindoo do honesto, acaba por cair na culpa, é é malvado ${ }^{43}$.

Sobre a pena, Cícero, determina que esta deve conservar uma medida eqüitativa, sua função não pode se restringir a provocar o arrependimento do culpável. Desse modo, confere a pena, também, uma função preventiva e, por fim, proíbe que se lhe aplique com cólera e ressentimento, não sendo lícito que seja utilizada para humilhar o réu ${ }^{44}$.

LUCIO ANNEO SENNECA. Para muitos o maior penalista da antigüidade, trabalhou as questões estritas do estoicismo, embora nem sempre rigido ou coerente. Sobre a pena, por exemplo, segue o ensinamento de Protágoras, Platão e Epicuro. Sêneca acolhe o argumento platônico e define a pena como "medicina da alma", assim, tal a medicina, a sanção pode produzir um

\footnotetext{
"1 CORTS GRAU, op. cit, p. 184; e, COSTA, op. cit, p. $26-7$.

12 Miguel Reale, entende o direto natural romano como un conjunto dos princípios primordiais do agir, que refletera, de maneira imediata e necessária, as obrigaçoes do homem enquanto homem, e como tais, imanentes do "jus gentium"(cf. Flosofia do direito, 19" ed. São Paulo: Saraiva, 2000, p. 632.)

\$ COSTA, op. it, p. 27

4. Ibid. p. 28
} 
sofrimento e inclusive resultar aparentemente nociva, mas quando atua como deve ser - exclusivamente ditada pela razão - produz a cura ${ }^{45}$.

O magistrado, até onde é possível, trata dos espíntos com a palavra, empregando as expressões mais doces, de maneira que possa persuadir a cada um do cumprimento de seu dever e inspirar a todos o sentimento de justiça. Passa depois a uma linguagem mais severa para oferecer uma advertência extrema. E só ao final recorre aos castigos: começa pelas penas ligeiras, sobressaindo as vezes, mediante o perdão; aplica depois aos grandes criminosos sanções mais graves. Tudo porque a pena surte mais efeito naquele que teme perder algo: ninguém respeita a própria dignidade se a considera perdida para sempre ${ }^{46}$.

Sêneca concebe uma única diferença da pena frente a medicina. Enquanto o médico procura um fim doce àquele que não pode salvar, o executor da lei rodeia a pena de um aparato desonroso. Isto ocorre não porque encontre alguma satisfação no castigo, mas para que o exemplo dos executados sirva a todos e a morte daqueles que não quiseram ser úteis, se converta em uma utilidade social ${ }^{47}$.

\section{Conclusão}

A teoria do jusnaturalismo, então, apóia-se na existência de leis objetivas que espelham uma ordem preestabelecida e na possibilidade de sua apreensão e cumprimento pelos homens. Com Hans Welzel afirma-se que o direito natural greco-romano dividese em duas teorias, o direito positivo fundamentado em: a) verdades racionais eternas; ou no, b) caráter vital instintivo.

$\mathrm{Na}$ Grécia surgiram as primeiras dúvidas e com essas as primeiras formas do saber humano. Ou seja, os gregos se notabilizaram dentre os antigos, por, pela primeira vez, realizarem e documentarem, um estudo sistemático da realidade que os cercavam. Os pensadores gregos pareceram fundir a vontade divina com a vontade humana. Porém, o individuo, descrito por eles, não possui o livre-arbítrio, era mero executor das idéias eternas ou agiu por instinto (por veneração, por temor e por interesse). Nesse contexto, Sócrates e Platão examinaram as relações entre o conhecimento e o mal, enquanto que Aristóteles delineou a teoria subjetiva da responsabilidade, a qual foi aperfeiçoada pelos juristas romanos.

\footnotetext{
45 COSTA, op. cit. p. 30; e, CORTS GRAU, op cit, p. 164

to COSTA, op. cit. p. 30; e, CORTS GRAU, op cit. p. 169

COSTA, op cit, p. 30-1.
} 
Importante destacar, ainda que, os romanos lidaram com o direito como se tivessem feito uma distinção deste com a moral, mas, em verdade, não aprofundaram a análise, não resolveram o problema no âmbito de uma indagação filosófica especifica. Pois como observa, Jürgen Habermas, em seus aspectos fundamentais o direito romano repetiu a explicação do direito como algo sagrado que influencia o profano.

Pode-se afirmar que, essa característica sagrada do direito será desnudada, com a transição para a Idade Média, na qual acentuar-se-á a fundamentação divina do direito natural e a questão do arbítrio individual receberá novo tratamento. Assim, no direito natural medieval ficará evidente a tensão entre o soberano que deve se submeter ao direito sagrado.

\section{BIBLIOGRAFIA}

BOBBIO, Norberto. Locke e o direito natural. Trad. Sérgio Bath. Brasília: UnB, 1997.

CHAUI, Marilena. Convite à filosofia. $12^{\circ} \mathrm{ed}$, São Paulo: Ática, 1999. CORTS GRAU, Jose. Historia de la filosofia del derecho. $2^{\circ} \mathrm{ed}$. Tomo I. Madrid: Nacional, 1968.

COSTA, Fausto. El delito y la pena en la historia de la filosofia. Trad. Mariano Ruiz-Funes. México: Uteha, 1953.

FALCON Y TELLA, Maria Jose. Concepto y fundamento de la validez del dercho. Madrid: Civitas, 1994.

FARIÑAS DULCE, Maria José. El problema de la validez jurídica. Prol. Gregorio Peces-Barba. Madrid: Civitas, 1991.

FUSTEL DE COULANGES, Numa Denis. A cidade antiga. Trad. Fermando de Aguiar. $4^{2}$ ed. São Paulo: Martins Fontes, 1998.

HABERMAS, Jürgen. Teoría da acción comunicativa. Tomo I: racionalidad de la acción y racionalización social. Trad. Manuel Jiménez Redondo. $1^{\prime \prime}$ ed. Madrid: Taurus, 1988.

HABERMAS, Jürgen. Direito e democracia: entre facticidade e validade. Trad. Flávio B. Siebeneichler. Rio de Janeiro: Tempo Brasileiro, 1997. vol. II.

HANSEN, Gilvan Luiz. Modernidade, utopia e trabalho. Prefácio de Leonardo Prota. Londrina: CEFIL, 1999.

MONDOLFO, Rodolfo. O pensamento antigo. Trad. Lycurgo Gomes da Motta. São Paulo: Mestre Jou, 1973. vol. I. 
PALOMBELLA, Gianluigi. Filosofía del derecho: moderna y contemporânea. Trad. José Calvo Conzález. Madrid: Tecnos, 1999. REALE, Miguel. Filosofia do direito. 19. ed. São Paulo: Saraiva, 2000. WELZEL, Hans. Introduccion a la filosofia del derecho: Derecho natural y justicia material. Trad. Felipe González Vicen. 2. ed. Madrid: Aguilar, 1974.

ZAFFARONI, Eugenio Raul. Manual de derecho penal: Parte general, 6. ed. Buenos Aires: Ediar, 1991. 